\title{
El arquitecto de retablos y escultor Martín Moreno y los primeros retablos con columnas salomónicas en Sevilla
}

\author{
Teodoro Falcón Márquez \\ Universidad de Sevilla
}

\begin{abstract}
RESUMEN: Martín Moreno ( $† 1677$ ?) fue un excelente arquitecto de retablos y escultor sevillano, activo entre las décadas de 1620-60, quien estuvo relacionado profesionalmente con los artistas más importantes del barroco de esta ciudad. Llegó a ser uno de los primeros en emplear la columna salomónica en los retablos de Sevilla, en la década de 1650. Como los artistas de su época refleja en sus obras que conocía a los grandes tratadistas de la arquitectura italiana. Asimismo se advierten influencias de los retablos de Martínez Montañés, de Alonso Cano, de Alejandro Saavedra y de los Ribas. En este ensayo, además del aparato crítico de la bibliografía, se aportan datos biográficos y documentales. De forma pormenorizada se analizan dos de sus empresas más representativas: el retablo de la capilla de la Concepción Grande, de la catedral de Sevilla (1656-1663) y el Mayor de la iglesia de Santa María la Blanca (1657-1658).
\end{abstract}

PALABRAS CLAVE: Martín Moreno, Retablo barroco sevillano, Catedral hispalense.

\section{The Architet-Jointer and Sculptor Martin Moreno and the First Altarpieces with Salomonic Columns in Seville}

\begin{abstract}
Martín Moreno ( $† 1677$ ?) was an excellent sculptor and architect-jointer, who worked between 1620 and 1660. He had relationship with the most important artists of Baroque in Seville and was one the first who used the Salomonic columns in the altarpieces of 1650. As the others artists in this epoch, he studied the main treatises of Italian architecture. Also we can see in his work the influence and similitude with the altarpieces by Martínez Montañés, Alonso Cano, Alejandro Saavedra and the Ribas, in his work. In this paper we are contributing with biographical data and unpublished historic documents, and with a review of bibliography. Specifically we analyse two of his most important works: The altarpiece of Chapel of La Concepción Grande, located in Seville Cathedral, and the main altarpiece of Church in Santa María la Blanca.
\end{abstract}

KEY WORDS: Martín Moreno, Baroque Altarpiece in Seville, Cathedral of Seville.

Recibido: 31 de enero de 2013 / Aceptado: 1 de marzo de 2013.

Martín Moreno fue un importante ensamblador, arquitecto de la madera y escultor sevillano, activo entre 1629 y la década de 1660, cuya labor no ha sido lo suficientemente valorada en la historiografía artística tradicional, habiendo quedado relegado a un segundo plano con relación a otros famosos ensambladores contemporáneos, tales como Francisco Dionisio de Ribas y Bernardo Simón de Pineda. Su personalidad y reconocimiento se vienen acrecentando en

* FALCÓN MÁRQUEZ, Teodoro: «El arquitecto de retablos y escultor Martín Moreno y los primeros retablos con columnas salomónicas en Sevilla», Boletín de Arte, n. ${ }^{\circ} 34$, Departamento de Historia del Arte, Universidad de Málaga, 2013, pp. 69-87, ISSN: 0211-8483. 
esta última década. Desarrolló una amplia actividad artística en el antiguo reino de Sevilla, que viene a coincidir con el marco de su diócesis. En la capital trabajó para la catedral, la iglesia de la Anunciación (antigua Casa Profesa de la Compañía de Jesús), la iglesia del Colegio de San Francisco de Paula y para los templos del Salvador, San Marcos, Santa María la Blanca, Santa Catalina, el Sagrario y el hospital de la Encarnación de Triana. En la provincia, en las iglesias de los conventos de Santa Ana de Carmona y de San Agustín de Osuna, además de las iglesias parroquiales de Gerena, Los Palacios y Santa María de Mesa de Utrera. En la provincia de Huelva, en las iglesias parroquiales de Santa María de la Asunción de Aracena, en la de la Asunción de Aroche y en la de Villalba del Alcor. Finalmente, en la provincia de Cádiz, en la iglesia del convento de San Francisco de Villamartín'.

Trabajó profesionalmente con el arquitecto Pedro Sánchez Falconete, maestro mayor de la ciudad, de la catedral y del arzobispado; con los ensambladores Felipe de Ribas y Blas de Escobar; con los entalladores y estofadores hermanos Borja, y con los escultores: Pedro Roldán, Alfonso Martínez (que fue su albacea testamentario), Juan Gómez Couto (también dorador)², Luis Ortiz de Vargas, Juan Pérez y Juan de Remesal. Entre los pintores laboró con Pedro Calderón (pintor de imaginería), Pablo Legot (su cuñado) y con Alonso de Zamora. Mantuvo contactos profesionales y de amistad con Alonso Cano, Martínez Montañés, Murillo y Valdés Leal. En 1638, junto con Martínez Montañés, Luis de Figueroa y Jerónimo Velázquez, dio poder a Alonso Cano para que en su nombre los representara en el pleito que sostenían los maestros ensambladores y escultores locales, contra el intrusismo profesional de los carpinteros de lo blanco. Colaboró con Murillo, Pedro Roldán, los hermanos Borja y Valdés Leal en la iglesia de Santa María la Blanca, tras su reconstrucción, contribuyendo a su patrimonio artístico. Del mismo modo coincidió con la mayoría de ellos en la renovación de la capilla de la Concepción Grande (antes dedicada a San Pablo) de la catedral. Prueba de una entrañable amistad, Murillo acogió a Martín Moreno, ya mayor, en su casa de la collación de San Bartolomé, donde consta que residía en 1677. Con Valdés Leal colaboró asimismo en 1658 en un retablo doméstico para Juan López. Este pintor

1 Para una visión general del artista, véase: HALCÓN, Fátima; HERRERA, Francisco y RECIO, Álvaro, El retablo barroco sevillano, Sevilla, Universidad-Fundación El Monte, 2000. HALCÓN, Fátima. "La imposición del orden salomónico en la retablística sevillana", El retablo sevillano desde sus orígenes a la actualidad, Sevilla, Diputación-Real Maestranza de Caballería-Fundación Cajasol, 2009, pp. 211-213.

2 Entre las numerosas referencias bibliográficas de sus obras, citaremos que Martín Moreno, Alfonso Martínez y Juan Gómez Couto, intervinieron en 1659 en el primitivo retablo de la Virgen de las Aguas, de la iglesia del Salvador. 
se erigió en difusor del nuevo prototipo de columnas salomónicas que vio en las trazas de Martín Moreno. El modelo de retablo de la citada capilla de la catedral, lo reflejó en el lienzo que representa a Fr. Pedro de Cabañuelas (Museo de Bellas Artes de Sevilla), realizado entre 1656-57, por lo que el pintor debió inspirarse en el proyecto, ya que entonces el retablo se estaba iniciando ${ }^{3}$. Mientras Martín Moreno laboraba en ese retablo de la catedral, Valdés colaboró en su dorado y estofado, así como diseñó la lápida conmemorativa y pintó las rejas de la capilla. También Valdés representó una columna salomónica, con decoración de pámpanos y vides, en el lienzo de Los Desposorios de la Virgen con San José, de la catedral (1657) 4

Como es frecuente en los artistas de la época, Martín Moreno cambió de vivienda con cierta frecuencia, tal vez motivado -como Murillo- por la aproximación a las obras que realizaba en cada momento. En 1629, cuando inicia su actividad profesional documentada, es vecino de San Juan de la Palma ${ }^{5}$. En 1633 consta que reside en la collación de San Andrés ${ }^{6}$, y en 1654 y siguientes en el Salvador ${ }^{7}$. Diez años después, viviendo en esta feligresía, suscribe su testamento en 29 de septiembre de 1664, ante el escribano Pedro de Gálvez. En él declara que estuvo casado en primera instancia con Luisa Francisca de Mendoza, y en la actualidad lo estaba con Ana de Rojas, a la que declara su heredera universal, ya que no tiene hijos, ni herederos forzosos. A ella le pide que acoja a Ana María Vela «mi suegra, que la sustente y tenga en su compañía». También manifiesta que a su muerte su cuerpo sea depositado en la iglesia del Salvador, que le oficien una misa de réquiem cantada, y otras 200 entre este templo y los que pareciera oportuno a sus albaceas testamentarios. Constan como tales: Alfonso Martínez, maestro escultor; Jerónimo López «mi compadre, maestro de hacer imaginería de pasta, y Alfonso Carrasco, maestro de hacer cajas para estuches, que todos tres son hermanos de

3 FALCÓN, Teodoro, "Valdés Leal y la arquitectura sevillana», Laboratorio de Arte, Sevilla, Universidad, 1991, p. 151.

4 Entre los frecuentes vínculos profesionales y de amistad existente entre los artistas citados, citaremos que Pedro Sánchez Falconete y Alfonso Martínez realizaron la portada de San Fernando (1655-57), que comunica la catedral con la iglesia del Sagrario. Alfonso Martínez fue miembro de la Academia fundada por Murillo, entonces presidida por Valdés Leal. Esos vínculos se transmitieron a sus hijos; así Felipe Martínez, hijo de Alfonso Martínez, se casó con una hija de Valdés Leal, y Lucas Valdés se casó con una hija de Francisco Dionisio de Ribas.

5 De las primeras apariciones documentadas, citaremos que el 5 de mayo de 1629 figura como fiador de Pablo Legot y Juan Remesal, quienes realizaban el retablo mayor de la iglesia de Aracena. Poco después, en 13 de junio, Pablo Legot traspasa a Martín Moreno la ejecución del ensamblaje y esculturas del retablo mayor de la iglesia parroquial de Los Palacios (Sevilla). LÓPEZ MÁRTíNEZ, Celestino, Retablos y esculturas de traza sevillana, Sevilla, Rodríguez Giménez y Cía., 1928, pp. 75-77, 106, 156-159.

6 LÓPEZ MÁRTínEZ, Celestino, Desde Martínez Montañés a Pedro Roldán, Sevilla, 1932, p. 108.

7 LÓPEZ MÁRTÍNEZ, Celestino, Arquitectos, escultores y pintores vecinos de Sevilla, Sevilla, Rodríguez Giménez y Cía. 1928, p. 106. KINKEAD, Duncan T., Pintores y doradores en Sevilla (1650-1699). Documentos, Bloomington (Indiana), 2007, p. 205. 
la Congregación del Santísimo Sacramento». Sin embargo sobrevivió más años. En 1669 vuelve a residir en la collación de San Andrés ${ }^{9}$. Finalmente en 1677 consta que vive en la collación de San Bartolomé, en la calle de San Jerónimo (hoy San Clemente, en la desembocadura de la plaza de los Curtidores), en la casa de Murillo, que le ha acogido cuando era de avanzada edad y se hallaba enfermo y de nuevo viudo ${ }^{10}$. Debió fallecer en ese año, aunque no consta que se enterrara en la iglesia de San Bartolomé en ese año, ni en los sucesivos.

Martín Moreno fue uno de los maestros ensambladores que emplearon por primera vez la columna salomónica en los retablos de esta ciudad. La aparición de ese modelo en el antiguo reino de Sevilla, tuvo lugar en el retablo mayor de la Cartuja de la Defensión de Jerez de la Frontera, realizado entre 1636-39, trazado por el artista extremeño afincado en Cádiz, Alejandro de Saavedra, quien contó con la colaboración del escultor flamenco José de Arce y con el pintor extremeño Francisco de Zurbarán. En este retablo, desaparecido, debió reinterpretarse a propuestas de Arce, recién llegado de Flandes y de Roma, el tipo de columna que había realizado Bernini para el baldaquino de la basílica de San Pedro en el Vaticano. El modelo había sido ampliamente difundido a través de grabados. Saavedra empleó este tipo de columnas en el retablo mayor de la catedral vieja de Cádiz (iglesia del Salvador), que se instaló en 1651. Sobre las fuentes iconográficas de donde pudieron tomar modelos los retablistas sevillanos para las columnas salomónicas, se ha especulado que pudo proceder de ilustraciones de tratados y otras publicaciones. Entre ellos se ha señalado la Regla de los cinco órdenes de Architectura, de Giacomo Barozzi da Vignola, edición de Patricio Caxés de 1593, en donde se le denomina "columna tuerta» (lam. 31). También se han buscado antecedentes en dibujos de Alonso Cano, tales como la Puerta salomónica o Detalle de retablo con columna salomónica (Biblioteca Nacional, Madrid). Sin embargo estos dibujos debieron de realizarse en su etapa granadina, entre 1652 y $1665^{11}$. También se suele citar el Tratado de la Pintura Sabia de fray

8 Archivo Histórico Provincial de Sevilla (AHPS). Oficio 19, legajo 12.971, fol. 606r-607r.

9 VALDIVIESO, Enrique; ILLÁN, Magdalena, Noticias artísticas sevillanas del Archivo Farfán Ramos. Siglos XVI-XVII-XVIII, Sevilla, Ediciones Guadalquivir, 2006, pp. 122-123.

10 Archivo parroquial de San Bartolomé. Padrón de 1677. Consta que vive en la casa n. ${ }^{\circ} 126$ de la feligresía, junto a Bartolomé, José y Gaspar Murillo, entre otros. De ellos destacaremos a Sebastián Gómez ("el Mulato" o "el Granadino»), esclavo morisco adquirido por Murillo, que fue su criado y ayudante. Siguió la estela de su maestro como pintor. Si nació en torno a 1655, como se ha manifestado, tendría entonces poco más de 20 años. Su primera obra conocida data de 1690. ANGULO ÍÑIGUEZ, Diego, Murillo, Madrid, Espasa Calpe, 1981, t. 1, p. 157. KINKEAD Duncan T., Pintores y doradores..., p. 372 . No figura Martín Moreno en el padrón de esa parroquia de 1676, ni en el de 1678.

11 MARÍAS FRANCO, Fernando, "Alonso Cano y la columna salomónica", Figuras e imágenes del Barroco. Estudios sobre el barroco español y sobre las obras de Alonso Cano, Madrid, Fundación Argentaria, 1999, pp. 291-321. 
Juan Rizzi, que no se publicó hasta 1930, aunque sus estampas fueron conocidas en los talleres artísticos. El original se conserva en la Biblioteca de la Fundación Lázaro Galdiano de Madrid. No se sabe con certeza la fecha de su realización, pero el hecho de que esté dedicado a Teresa Sarmiento de la Cerda, duquesa de Béjar, que no ostentó el título hasta 1660, sitúa la obra en fecha posterior a los primeros retablos de Martín Moreno.

Además de la probable formación erudita de estos artífices, el planteamiento hay que buscarlo en otro ámbito. Si en el retablo de la catedral vieja de Cádiz colaboraron con Alejandro Saavedra el escultor Alfonso Martínez y el pintor-dorador Juan Gómez Couto, que van a ser asiduos colaboradores de Martín Moreno, y tenemos presente la colaboración de Felipe de Ribas en la cartuja de Jerez con el mismo ensamblador, así como la formación con él de Bernardo Simón de Pineda en Cádiz, documentada en 1651, todo ello subraya la conexión jerezana-gaditana de estos artífices, que van a realizar retablos con columnas salomónicas en Sevilla entre las décadas de 1650-7012. Posiblemente el primer retablo de este estilo ejecutado en Sevilla debió ser el concertado en 1646 por Felipe de Ribas para el retablo mayor de la iglesia del convento de la Merced (hoy Museo de Bellas Artes), que no se conserva. Su descripción la conocemos a través de testimonios contemporáneos, así como de una visión lejana que figura en el Retrato de fray Alonso de Sotomayor realizado en 1657 por Valdés Leal. Casi simultáneamente vendría el de la Concepción Grande de la catedral, iniciado en 1656, y el Mayor de la iglesia de Santa María la Blanca, comenzado al año siguiente, aunque concluido antes que el anterior. Como veremos, en los esquemas compositivos de Martín Moreno se advierte la influencia del frontispicio de Los cuatro Libros de Arquitectura (I quatro libri dell'architettura), de Andrea Palladio, editado en Venecia en 1570, del que hay una edición castellana de Francisco de Praves, publicada en 1625. También hay ecos de los retablos de Martínez Montañés y de los hermanos Ribas, mas influencias de Alonso Cano y del Tratado de Arquitectura de Wendel Dietterlin ${ }^{13}$. También se advierten influen-

12 SANCHO, Hipólito, "El escultor Alfonso Martínez en Cádiz», Archivo Español de Arte, XXI, Madrid, 1948, pp. 189-199. KINKEAD, Duncan T., "Alonso Martínez: nuevos datos para su biografía», Juan de Mesa y la escultura andaluza de su tiempo, Jornadas con motivo del cuarto centenario de su muerte, Sevilla, 1983, p. 3. RECIO MIR, Álvaro, "Alfonso Martínez, escultor en piedra en el Sagrario de la catedral de Sevilla", Archivo Hispalense, Sevilla, Diputación, 2001, n. ${ }^{\circ}$ 256-57, pp. 197-209. ROMERO DE TORRES, José Luis, "Bernardo Simón de Pineda y su aprendizaje en Cádiz con el arquitecto de retablos Alejandro de Saavedra", Laboratorio de Arte, n. ${ }^{\circ}$ 19, Sevilla, Universidad, 2006, pp. 173-194. ROMERO DE TORRES, José Luis, "Una importante renovación estética en la década de 1650: la modernización de las catedrales andaluzas», Congreso Internacional Andalucía Barroca, Sevilla, Junta de Andalucía, 2007, tomo I, pp. 417-430. 13 Estrasburgo, 1598. Hay una edición de 1655 en la Biblioteca del Museo Nacional del Prado. Para la influencia de este tratadista en el barroco sevillano, véase: FALCÓN MÁRQUEZ, Teodoro, "La influencia 
cias de los hermanos Ribas: Felipe (†1648) y, sobre todo de Francisco Dionisio, especialmente en la decoración a base de almohadillados, por lo que algunos de sus retablos se han considerado como obras de estos artistas cordobeses. En su primer testamento no se hace alusión a los libros que poseía. Sin duda debió tener las obras de los grandes tratadistas de la arquitectura italiana. En este trabajo analizamos dos de los retablos más representativos de este maestro ensamblador.

\section{Retablo de la capilla de la Concepción Grande de la catedral}

La primitiva capilla de San Pablo, ubicada en la cabecera de la catedral, entre la Capilla Real y la Puerta de Campanillas, como todas las periféricas del templo, es de planta rectangular y se cubre con bóveda de nervaduras sexpartita. En ella presidía un retablo gótico, con tablas renacentistas, hasta que se construyó el nuevo, a mediados del siglo XVII, al concedérsele esta capilla a Gonzalo Núñez de Sepúlveda, como panteón funerario. El titular era un capitán lisboeta, afincado en Sevilla, donde se casó en la iglesia del Sagrario el 15 de junio de 1631, con la sevillana doña Mencía de Andrade. El matrimonio estableció su residencia en la actual calle Cervantes, en el edificio que ocupa la Comunidad de Esclavas del Sagrado Corazón. Gonzalo Núñez amasó una importante fortuna con el comercio americano, Ilegando a desempeñar en 1635 el cargo de Veinticuatro de la ciudad y, con posterioridad, a ostentar el hábito de Caballero de la Orden de Santiago ${ }^{14}$.

La dotación de la capilla fue suscrita por este personaje el 10 de febrero de 1655 , postrado en su lecho a causa de la gota, dejando al deán y cabildo catedral como patronos y administradores perpetuos de ella, ya que no tenía hijos. La concesión de la capilla como panteón, se hizo en virtud de una amplia dote que el lusitano había establecido para la fiesta de la Inmaculada y su Octava, en la que incluía dotaciones matrimoniales para 20 doncellas, mas capellanías de misas, entre otras concesiones. En el patronazgo aportaba 8.000 ducados para la obra de la iglesia del Sagrario, lo que sumado a los gastos de las fiestas de la Inmaculada y de esta capilla, ascendía a más de 150.000 ducados. Núñez de Sepúlveda falleció el 24 de noviembre de 1655, siendo enterrado en la cripta de

de los grabados fantásticos de Dietterlin en la arquitectura barroca sevillana", Laboratorio de Arte, n. ${ }^{\circ}$ 21, Sevilla, 2009.

14 DE LA CAMPA Y CARMONA, Ramón, "Un ejemplo de patronazgo nobiliario en la catedral de Sevilla: la capilla de la Concepción Grande y don Gonzalo Núñez de Sepúlveda", El comportamiento de las catedrales españolas del barroco a los historicismos, Murcia, Universidad de Murcia, 2003, pp. 425-447. 
su capilla al día siguiente. Su cuerpo iba armado como caballero, con espuelas, botas y manto de la Orden de Santiago. El finado inauguró la capilla sin que se hubiese iniciado el nuevo retablo ${ }^{15}$. En el testamento se hace constar que la capilla, renovada, se llamase «de la Pura y Limpia Concepción de Nuestra Señora y Señor San Pablo». En el nuevo retablo se pidió por el cabildo que se dejara el crucificado primitivo, conservando las indulgencias concedidas por Su Santidad a los fieles que lo venerasen.

A partir de entonces su viuda y albaceas testamentarios se ocuparon de la realización del nuevo retablo y del exorno de la capilla. Previamente decidieron quitar el retablo primitivo. En 25 de junio de 1657 el cabildo acordó trasladarlo a la Antesacristía Mayor, aunque en un nuevo acuerdo de 6 de septiembre de ese año se decidió donarlo a la iglesia de San Roque. El porte definitivo no se efectuó hasta dos años después. En ese templo desaparecería tras el incendio de $1759^{16}$. Del primitivo retablo sabemos que se había comenzado a renovar en 1530, cuando se contrató al pintor Pedro Fernández de Guadalupe, aunque no se concluyó hasta 1543, interviniendo entonces el entallador Gómez de Orozco y los pintores Juan Sánchez y Antón Pérez. Se trataba de un retablo de tres calles, con pinturas al óleo sobre tablas. En el primer cuerpo presidía la imagen titular de San Pablo, y a sus lados las escenas que representaban su conversión, cayendo del caballo, y su martirio, con la decapitación. En el segundo presidía el crucificado -que perdura- mayor del natural, cuya autoría ha sido vinculada recientemente por Gómez Piñol a Jorge Fernández Alemán, debiendo realizarse entre 1530-4017.

Respecto al nuevo retablo la bibliografía es relativamente abundante, aunque ha cambiado de criterio con frecuencia sobre la autoría de sus artífices. Posiblemente la primera publicación en la que se alude a él, fue realizada pocos años después de su conclusión. Se trata de una obra de Torre Farfán, alusiva a las fiestas por la canonización de San Fernando en $1671^{18}$. Al describir esta

15 Archivo de la catedral de Sevilla (ACS), Sección IX, Leg. 149, Doc. 24-25-26: Fundación de la dotación. Íd. Leg. 150, 1-10: Testamento de Gonzalo Núñez de Sepúlveda y sus títulos de dotación (16551770). Íd. Sección 5a. Patronatos. Libro 393: «Libro de las dotaciones que en esta sancta Iglesia fundó la buena memoria de don Gonçalo Núñez de Sepúlveda..." (1654-1723).

16 ACS, Sección I, Libro de Autos capitulares n. ${ }^{\circ} 64$ (07112), ff. 34 v. y 51r. Íd., Sección IV, Fábrica, Libro de Mayordomía, n. ${ }^{\circ} 170$ (09504), f. 1v.

17 SERRERA, Juan Miguel, "Pinturas y pintores del siglo XVI en la catedral de Sevilla», La catedral de Sevilla, Sevilla, Ediciones Guadalquivir, 1991, p. 361. GÓMEZ PIÑOL, Emilio, "Sentimiento religiosos en imágenes del crucificado en el arte hispanoamericano del siglo XVI», Signos de evangelización: Sevilla y las hermandades en Hispanoamérica, Sevilla, Fundación El Monte, 1999, p. 73.

18 TORRE FARFÁN, Fernando de la, Fiestas de la S. Iglesia metropolitana, y patriarcal de Sevilla, al nuevo culto del Señor Rey S. Fernando el Tercero de Castilla y de León, concedido a todas las Iglesias de España, por la Santidad de Nuestro Beatíssimo Padre Clemente X. Ofrécelo a la Augusta Magestad de Don Carlos II, N. S. Rey de las Españas, la misma Iglesia y escriviolo de orden superior Don Fernando 
capilla manifiesta: "preside en ella la imagen de Nuestra Señora, en el Misterio Purísimo de su Concepción, para cuya colocación moderna, se vistió de nuevo su capacidad, con rico, y grande retablo de admirable escultura, estofando de oro sus bóvedas y paredes, a expensas del piadoso lusitano Gonzalo Núñez de Sepúlveda». En la descripción no alude a sus autores. Las primeras referencias sobre uno de los artistas la hizo el conde del Águila (1781), cuando manifiesta que "la imagen de la Concepción que allí ai, y el retablo todo, se sabe que son de Alfonso Martínez" ${ }^{19}$. Con posterioridad Espinosa y Cárcel, en las Adiciones a los Anales de Ortiz de Zúñiga (1796), indica que la talla de la Inmaculada es de Martínez Montañés ${ }^{20}$. En el siglo XIX las primeras referencias las hizo Ceán Bermúdez (1804), quien declara que los albaceas del citado lusitano «encargaron la traza y execución del retablo a Francisco de Ribas [...]. Trabajó Alfonso Martínez las estatuas que contiene. Todas tienen naturalidad y corrección, pero carecen de aquella gracia que el Montañés, maestro de Martínez, daba a las suyas»"21. Años después González de León (1844) mantiene la atribución a Ribas y Alonso Martínez, añadiendo que el crucificado que lo preside unos lo atribuyen a Luisa Roldán, y otros a Alonso Cano ${ }^{22}$. También Gestoso sostiene la atribución a Ribas ${ }^{23}$.

En el siglo XX, la primera aportación documental fue la de López Martínez (1928), quien declara que fue Martín Moreno, maestro entallador y arquitecto, quien otorgó carta de pago el 14 de marzo de 1658 por importe de 2.000 reales a los albaceas testamentarios "por cuenta del retablo, hechura y madera que se está haciendo para la capilla» ${ }^{24}$. Hernández Díaz recoge este dato, sin embargo mantiene la atribución de las trazas a Francisco Dionisio de Ribas ${ }^{25}$, hipótesis

de la Torre Farfán, presbítero, natural de Sevilla. Con licencia. En Sevilla, en casa de la viuda de Nicolás Rodríguez, este año de 1671, p. 206.

19 CARRIAZO, Juan de Mata, "Correspondencia de D. Antonio Ponz con el conde del Águila", Archivo Español de Arte y Arqueología, Tomo V, Madrid, 1929, pp. 157-183.

20 ESPINOSA Y CÁRCEL, Antonio María, Anales eclesiásticos... de Ortiz de Zúñiga, ilustrados y corregidos, Madrid, 1796, tomo III, p. 236, nota 1.

21 CEÁN BERMÚDEZ, Juan Agustín, Descripción artística de la catedral, Sevilla, en casa de la viuda de Hidalgo y Sobrino, 1804, pp. 64-65. Íd. Diccionario histórico de los más ilustres profesores de las Bellas Artes en España. IV, Madrid, 1880, p. 183. Se refiere a Alonso Martínez, como discípulo de Martínez Montañés.

22 GONZÁLEZ DE LEÓN, Félix, Noticia artística, histórica y curiosa de todos los edificios públicos, sagrados y profanos de esta...ciudad de Sevilla y de muchas casas particulares, Sevilla, imprenta de D. José Hidalgo y Compañía, 1844, pp. 387-388.

23 GESTOSO Y PÉREZ, José, Sevilla Monumental y Artística, Tomo II, Sevilla, 1890, p. 361.

24 LÓPEZ MARTÍNEZ, Celestino, Arquitectos, escultores..., p. 106.

25 HERNÁNDEZ DÍAZ, José, "Papeletas para la historia del retablo en Sevilla durante la segunda mitad del siglo XVII", Boletín de Bellas Artes, Sevilla, 1935, pp. 6-7. HERNÁNDEZ DÍAZ, José, "Escultura del siglo XVII". Summa Artis, Vol. XXVI, Madrid, Espasa-Calpe, 1983, p.112. El autor mantiene que Alfonso Martínez colaboró con los Ribas en este retablo. 
que no comparte María Teresa Dabrio ${ }^{26}$. Por su parte Paulina Ferrer sugirió que el autor de las trazas del retablo debió ser Bernardo Simón de Pineda ${ }^{27}$. Más recientemente, a comienzos del siglo XXI, Ramón de la Campa (2003) y Kinkead (2006), han aportado nuevos datos documentales, que convienen ordenar cronológicamente. Así en 19 de diciembre de 1656, Pedro de Borja, "maestro mayor de este arzobispado en facultad de entallador y estofador", presentó carta de pago por importe de 3.101 reales de vellón, de 34 maravedíes, por el estofado y dorado de la talla de la Inmaculada, de Alonso Martínez. Al año siguiente, en febrero de 1657, los hermanos Pedro, Pablo y Felipe de Borja Machado, declaran que está obligados a participar en el retablo que Martín Moreno y Alfonso Martínez, maestro escultor y ensamblador, respectivamente, están haciendo, cuya labor se comprometen a estar acabada a fines de septiembre de 1658 . El precio estipulado fue de 6.000 ducados. Su labor consistía en encarnar y estofar las imágenes de los santos, el Dios Padre, el crucificado, los ángeles y la ornamentación de las columnas salomónicas. Sin embargo las fechas del contrato se incumplieron.

A lo largo de 1659 constan cinco pagos a Pedro de Borja por el dorado y estofado del retablo, pagos que proseguían al año siguiente. En 15 de marzo de ese año de 1660, el mismo artista manifiesta tener percibidos $66.000 \mathrm{rs}^{28}$. En 20 de marzo de ese año Alfonso Martínez y Martín Moreno suscribieron carta de pago por importe de 8.500 rs., de los cuales 3.000 eran "por la madera y hechuras de la imagen de la Fe y dos medios cuerpos de las santas Justa y Rufina, y 5.500 por la madera y hechuras de la moldura grande del remate y otros pedazos de obra con que se remata el retablo». Meses después, en 24 de diciembre del mismo año de 1660, Martín Moreno firmó carta de pago de 1.000 rs. por una moldura y tres repisas, y Pablo de Vaxa 663 rs. por el dorado de estos elementos ${ }^{29}$. En 27 de abril de 1661 Pedro y Pablo de Borja percibieron 42.000 rs., de a 34 maravedíes, por «dorar de oro oscurecido todos los cascos altos y el arco principal». Su labor debería estar acabada en dos meses ${ }^{30}$. Sin embargo las obras se paralizaron. En los cabildos celebrados en la catedral en septiembre y octubre de ese año se denuncia que la capilla lleva años llena de andamios, por lo que dan un ultimá-

26 DABRIO GONZÁLEZ, María Teresa, Los Ribas. Un taller andaluz de escultores del siglo XVII, Córdoba, Monte de Piedad y Caja de Ahorros de Córdoba, 1985, pp. 479-480.

27 FERRER GARROFÉ, Paulina, "Bernardo Simón de Pineda. Arquitectura en madera", Arte Hispalense, n. ${ }^{\circ}$ 32, Sevilla, Diputación, 1982, p. 46. FERRER GARROFÉ, Paulina, "Retablo de la Concepción Grande», Catálogo de la Exposición Sevilla en el siglo XVII. Sevilla, 1983, p. 163.

28 Archivo Histórico Provincial de Sevilla (AHPS) Oficio 21, Escribanía de Juan Rodríguez de Laoysa, Leg. 14584, ff. 243r-247v. KINKEAD, Duncan T., Pintores y doradores..., pp. 72-76.

29 DE LA CAMPA Y CARMONA, Ramón, "Un ejemplo de patronazgo...", p. 440.

30 AHPS, Leg. 14.584, ff. 243r-247r. 
tum a los artistas para que finalicen las obras. Todavía dos años después, en 2 de enero de 1663, Pablo de Borja suscribía carta de pago por importe de 4.152 rs. por el estofado y dorado de la capilla. Sin embargo resulta sorprendente que cuatro meses después, en 8 de mayo, Juan de Valdés Leal se concertara por importe de 12.500 rs., por dorar y estofar el retablo, lo que evidencia que los Borja no lo habían concluido ${ }^{31}$. Por entonces estos hermanos estaban ocupados en la finalización de la iglesia del Sagrario, para donde hicieron en 1662 una monumental carroza, en forma de nave, para la Inmaculada Concepción de Martínez Montañés (la "Cieguecita»), con motivo de la procesión que hubo previa a la inauguración del templo ${ }^{32}$. Al parecer también participaron activamente en la decoración de las bóvedas de la iglesia de Santa María la Blanca, lo que tuvo lugar entre 1664-65 cuando se hicieron las yeserías de las bóvedas ${ }^{33}$.

En conclusión, a la luz de las últimas aportaciones documentales, tenemos que descartar la intervención en este retablo de la catedral de Francisco Dionisio de Ribas y de Bernardo Simón de Pineda. Esta monumental pieza se inició en 1656, según trazas del ensamblador Martín Moreno, al mismo tiempo que Alfonso Martínez ejecutó las tallas y relieves, a excepción del crucificado que procede del retablo anterior. La imagen de la Inmaculada Concepción fue dorada y estofada el citado año por Pedro de Borja. A comienzos de 1657 debió estar concluida la parte arquitectónica del retablo, ya que en febrero de ese año los hermanos Borja iniciaron la labor de su estofado y dorado que debió estar finalizado, en gran medida en 1661. Por otra parte en enero de 1663 Pablo de Borja se concertó para la ejecución del dorado y estofado de la capilla, que afectaba a la bóveda y los muros. Sin embargo en 8 de mayo de ese año se encargó a Juan de Valdés Leal que concluyera el dorado y estofado del retablo. La cantidad que se le adjudica así lo avala también.

El retablo consta de banco, en el que hay ángeles-niños como atlantes, guirnaldas de frutos y tableros con decoración vegetal; luego viene un alto cuerpo de tres calles, que se organiza con cuatro columnas salomónicas de orden gigante de cinco espiras y de orden compuesto, decoradas con pámpanos y

31 ACS, Sección IV, Libro de Cuentas particulares, 04537 (518), Fol.16 vto (al margen: Juan de Valdés, maestro pintor) "Doce mil y quinientos rs. que se concertó el dorado y estofado del retablo de Sr. San Pablo, capilla de esta Santa Iglesia, de que en este día se despachó certificación para que los señores contadores mayores los libren por cuenta del Cabildo, por Auto de 8 de mayo de 1663, tomando hacer a su costa".

32 FALCÓN, Teodoro, La capilla del Sagrario de la catedral de Sevilla, Sevilla, Diputación, 1977. FALCÓN, Teodoro, «Procesión conmemorativa con motivo del estreno de la iglesia del Sagrario. Documento pictórico del entorno de la catedral de Sevilla en 1662", Laboratorio de Arte, n. ${ }^{\circ} 12$, Sevilla, Universidad, 1999, p. 141. 33 FALCÓN, Teodoro, "La iglesia de Santa María la Blanca de Sevilla, punto de encuentro entre Murillo y Justino de Neve", en Catálogo de la Exposición Murillo \& Justino de Neve. El arte de la amistad, Madrid, Museo Nacional del Prado, 2011, pp. 61-71. 


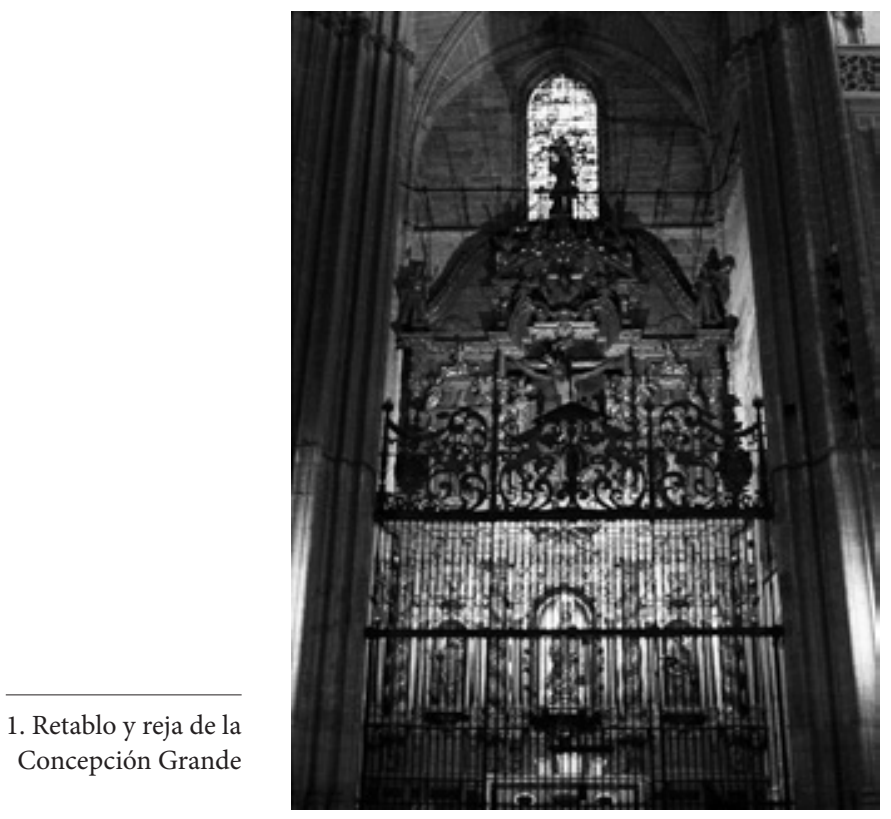

vides, que alternan con otras torsas, o entorchadas, de menor escala, que enmarcan las imágenes [1]. Son de mayores proporciones las que flanquean este cuerpo, rematadas en un trozo de entablamento. Estos trozos de entablamento y la decoración de guirnaldas de frutos los había empleado Alonso Cano en el retablo mayor de la iglesia de Nuestra Señora de la Oliva de Lebrija (1629-39). La alternancia de un orden gigante con otro normal, lo utilizó Martínez Montañés en el retablo mayor del monasterio de San Isidoro del Campo (1609-13) y Alejandro de Saavedra en el retablo mayor de la catedral vieja de Cádiz (terminado en 1651). En el primer cuerpo de este retablo sevillano preside la imagen de bulto redondo de la Inmaculada Concepción, Ilamada la Concepción Grande, por su tamaño (unos $2 \mathrm{~m}$ de alto) [2]. Se halla sobre una nube con seis querubines. El modelo mariano evoca modelos montañesinos, aunque con matices diferentes. Debemos llamar la atención en el soporte donde apea la Virgen, porque recuerda el que hay en el coronamiento del retablo mayor de la iglesia de Santa Cruz, de Cádiz, obra de Alejandro Saavedra, con la decoración escultórica de Alfonso Martínez. La embocadura de su hornacina se adorna con querubines y en el intradós hay relieves alusivos a las Letanías. En las calles laterales se ubican las imágenes de San José con el Niño y San Pablo [3], en recuerdo de la advocación del retablo primitivo. Sobre las hornacinas laterales figuran relieves de jarras de 


\section{Q: artículos}

Teodoro Falcón Márquez

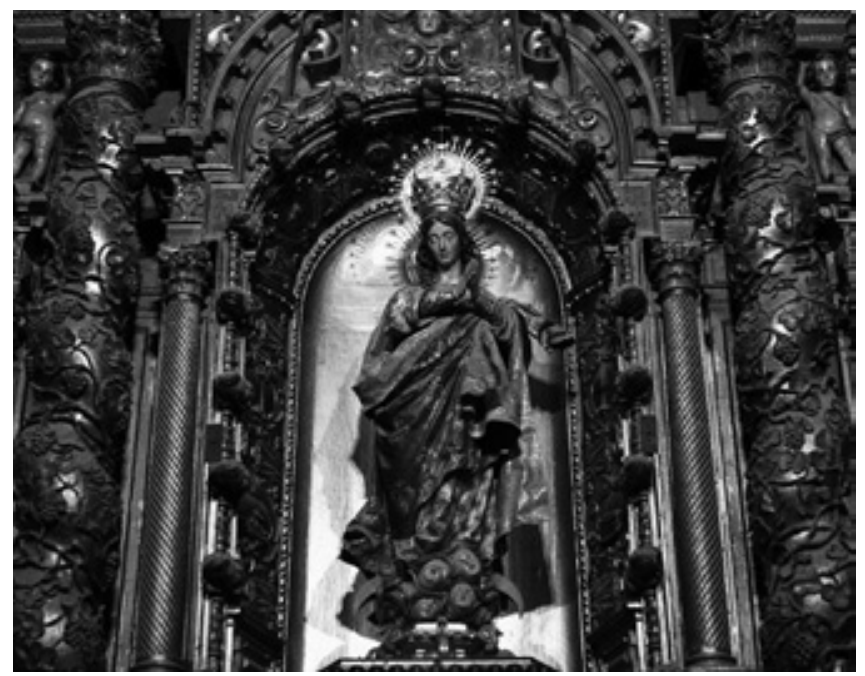

2. Inmaculada

Concepción

azucenas y tallas de ángeles-niños como atlantes. Un frontón roto y enroscado enlaza con el segundo cuerpo, de menores proporciones y en donde se repite la misma alternancia de columnas, prescindiendo de las extremas. Dentro de una hornacina cruciforme, preside el crucificado de hacia 1530-40, atribuido a Jorge Fernández [4]. Alfonso Moreno añadió a sus pies dos ángeles-niños pasionarios. Le flanquean las tallas del lisboeta San Antonio de Padua y del dominico San Gonzalo de Amarante, homónimo de Núñez de Sepúlveda. Sobre ellos hay hornacinas con los bustos de las santas sevillanas Justa y Rufina. Sobre otro frontón roto y enroscado hay un altorrelieve del Padre Eterno, y la representación escultórica de las cuatro virtudes cardinales, ubicando en los extremos a la Justicia y la Fortaleza. Sus atributos son los siguientes: Prudencia (con espejo), Justicia (con espada), Fortaleza (con columna) y Templanza (con freno). Culmina el retablo con la imagen de la Fe, virtud teologal. Bajo un gran arco hay un testero con decoración almohadillada, tema que divulgaron los hermanos Ribas. Los frontones rotos y curvos, con ángeles recostados, se inspiran en el frontispicio del Tratado de Andrea Palladio.

La construcción del nuevo retablo trajo implícito la ejecución de la sacristía, que se llevó a cabo bajo la dirección de Pedro Sánchez Falconete en otoño de $1657^{34}$. Para ella se hizo en 1660 por Murillo el lienzo del Nacimiento de la Virgen

34 CRUZ ISIDORO, Fernando, Arquitectura del siglo XVII. Maestros mayores de la catedral y del Concejo hispalense, Sevilla, Universidad, 1997, p. 71. 


2. artículos $\quad$ El arquitecto de retablos...

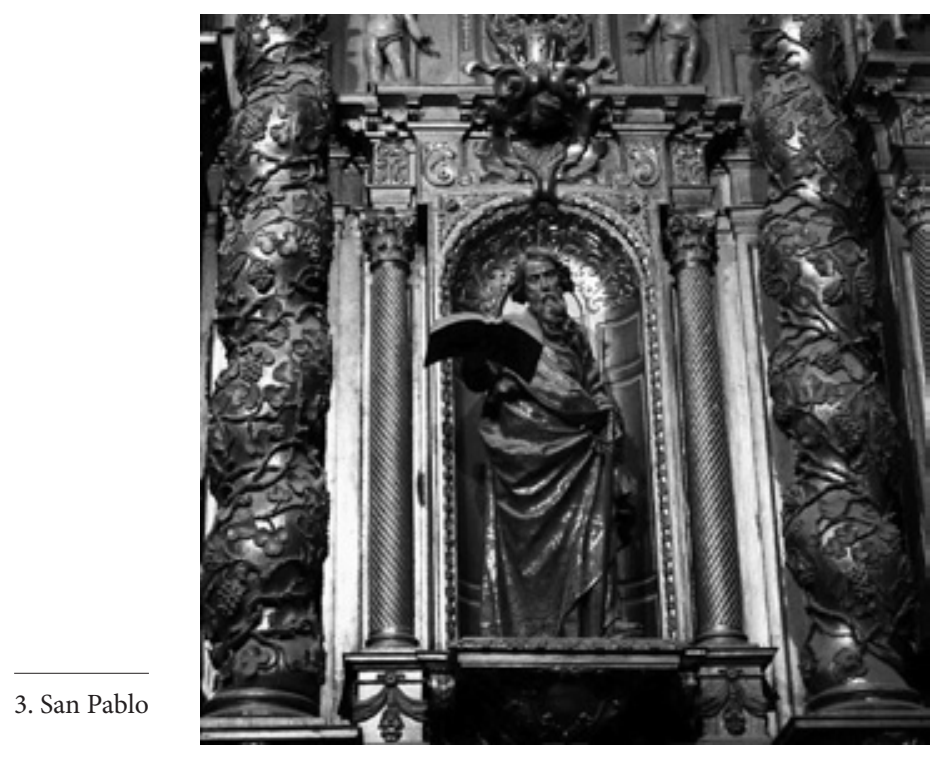

4. Segundo cuerpo con el Crucificado

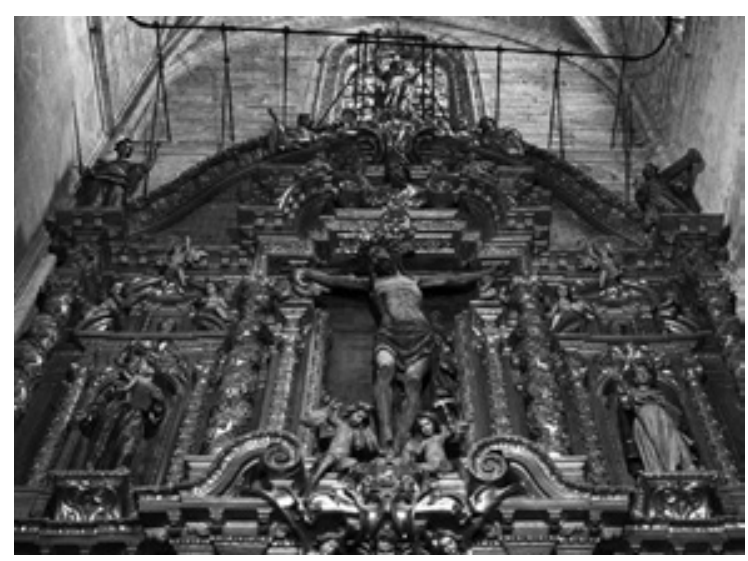

(Museo del Louvre) ${ }^{35}$. También participó de nuevo Valdés Leal, además del retablo, en la lápida conmemorativa y en el dorado de la reja. En 1664 se colocó en el lado del evangelio de la capilla una orla laudatoria de Núñez de Sepúlveda, de jaspe negro, con decoración dorada, diseñada por Valdés y ejecutada por el cantero Juan Donaire, el mismo que puso la solería ${ }^{36}$. La lauda se remata con una

35 Mide 1,84 x 2,60 m. ANGULO ÍNIIGUEZ, Diego, Murillo..., pp. 53, 152, 301-304, t. 2, pp. 135-137. 36 AHPS, Leg. 3701, Fol. 22. DE LA CAMPA Y CARMONA, "Un ejemplo de patronazgo...", p. 438. 
orla ovalada, decorada con volutas, en la que figura en un escudo cuartelado las armas de los apellidos de Núñez de Sepúlveda y de Andrade. Del primero son los castillos de oro con la torre del homenaje, la espada, la cabeza de moro y las flores de lis. De Andrade, la banda engolada en cabezas de dragantes, flanqueadas por jarras de azucenas. En la bordura hay ocho cruces aspadas de San Andrés (Núñez), alternando con cinco lobos (Andrade). La nueva reja se hizo en 1666. En 16 de febrero Valdés Leal se concertó con Isidro Velázquez, albacea testamentario de Núñez de Sepúlveda, "para dorar sobre color azul la reja de hierro [...] con las calidades y forma de un diseño en que en demostración están dos balaustres y la parte que de ellos ha de ser azul y lo demás dorado [...]". El presupuesto ascendió a 21.000 reales de vellón. El tiempo estipulado fue de tres meses, desde la fecha del contrato ${ }^{37}$. El resultado fue la mayor reja del siglo XVII de la catedral. Su estructura es de dos cuerpos más ático, en el que hay cuatro flameros. En el centro figura una Inmaculada apocalíptica, rodeada de dos figuras quiméricas. Se remata en un frontón triangular con decoración de venera y, sobre él el grupo de la deesis. A la derecha se halla el blasón de Núñez de Sepúlveda, y a la izquierda el de Andrade. Ya que generalmente las rejas las diseñaron los maestros mayores de la catedral, no me extrañaría que la trazara Pedro Sánchez Falconete, quien desempeñaba tales funciones. El tipo de frontón citado es característico suyo.

\section{Retablo mayor de la iglesia parroquial de Santa María la Blanca}

Es también, como el anterior, uno de los primeros en los que se emplearon las columnas salomónicas en esta ciudad. Se hizo simultáneamente al de la catedral, aunque se inició un año después y se concluyó mucho antes. Sus orígenes se remontan a 1657. El 23 de julio de ese año, el canónigo Justino de Neve, en calidad de visitador de las capillas de la catedral, notificó al cabildo que había recaudado limosnas para su realización ${ }^{38}$. Esta institución lo dio por bueno, comisionándole para vender el retablo anterior e indicando que su producto se invirtiera en la ejecución del nuevo. Las yeserías que decoran esta capilla, lo mismo que el resto de la nave central, debieron correr a cargo de los hermanos

37 ACS, Sección IV. Libro de Cuentas particulares 04537 (518). Fol. 34v-35r. Alfredo J. Morales ya publicó que el retablo primitivo se trasladó a la Antesacristía Mayor: "Artes aplicadas e industriales en la catedral de Sevilla", La catedral de Sevilla, Sevilla, Ediciones Guadalquivir, 1984, p. 566.

38 ACS, Sección I, Libro de Autos capitulares n. ${ }^{\circ} 64$, Fol. 4. 
Borja en colaboración tal vez de Pedro Roldán. Aunque se ha atribuido tradicionalmente a Francisco Dionisio de Ribas, lo cierto es que el 31 de agosto de 1657 se contrató para la ejecución del retablo a Martín Moreno ${ }^{39}$, el mismo maestro ensamblador que había ejecutado la sillería de coro de esta iglesia ${ }^{40}$. El contrato del retablo lo suscribió también Justino de Neve, ante el escribano Pedro de Gálvez ${ }^{41}$. Figuran como testigos Juan Carrillo y Alonso de Valdés. En el documento consta que Martín Moreno se comprometía a realizar «una obra de arquitectura, escultura, talla y ensamblaje» del retablo, según "traza y dibujos que tenía hecha de mi mano". A diferencia del retablo de la Concepción Grande de la catedral, en este lo hizo él solo, sin la colaboración del escultor Alonso Martínez y de los hermanos Borja, para la decoración. La obra, en madera de borne y cedro, debía estar acabada a fines de julio de 1658, por la que percibiría 14.000 reales de plata. Si comparamos los tiempos y la cuantía de ambos retablos, el de la catedral no se concluyó hasta 1663, y su costo fue más considerable, por sus dimensiones, por la intervención de más mano de obra y por las diversas dilaciones.

El resultado fue un espléndido retablo barroco [5], que consta, de abajo arriba, de banco muy retallado con temas florales, como las calles laterales, en el que se ubica el sagrario de plata ${ }^{42}$, flanqueado por las tallas en cedro de San Pedro y San Pablo [6]. Miden: 0,39 m de alto y conservan su policromía y estofado. San Pedro viste túnica verde-azulado, con decoración vegetal dorada y manto Jacinto. San Pablo viste con túnica verde, con ramaje dorado y capa jacinto con vueltas doradas. Las espléndidas imágenes están enmarcadas por pares de columnas retaIladas de orden dórico y basa ática [7]. Luego sigue un cuerpo, enmarcado por dos columnas salomónicas, con basa ática, de orden compuesto, con cinco espiras, que apean sobre repisas con tallas de querubines. En la parte superior hay tallas de serafines. Las columnas, sin decoración de pámpanos y vides, llevan esgrafiadas hojas de palmeras muy estilizadas, sobre fondo dorado. Recientemente se le ha añadido un crucifijo, atribuido a Juan de Mesa, fechable hacia 1620. En el centro hay un camarín, que alberga la imagen titular, la Virgen de las Nieves. Ese es-

39 AHPS, Leg. 12.950, Fol. 1160-1162. QUILES, Fernando, Teatro de la gloria. El universo artístico de la catedral de Sevilla en el Barroco, Sevilla, Diputación, 2007, pp. 388-389.

40 FALCÓN MÁRQUEZ, Teodoro, "La iglesia de Santa María la Blanca..." en Catálogo de la Exposición Murillo \& Justino de Neve, pp. 67-68.

41 «Pedro de Gálvez, escribano de número de esta ciudad de Sevilla, entró por hermano de estas santas cofradías (Sacramental y de la Virgen del Pópulo) en 10 de julio de 1672 . Falleció en 23 de octubre de 1682». Archivo de la iglesia de Santa María la Blanca (depositado en la iglesia de San Nicolás). Libro n. ${ }^{\circ}$ 2 donde se asientan los hermanos de estas Cofradías, que se inicia en 1650. Fol. 115.

42 La puerta del Sagrario mide: 0,51 x 0,31 m. Es de plata repujada y está decorada con la imagen del pelícano, ces y frutas. En la base muestra la marca y contraste: 79 CARD/AMAT. Debe tratarse de los plateros Fernando Nicolás de Cárdenas y Fernando Amat y Garay. La fecha es 1779. 

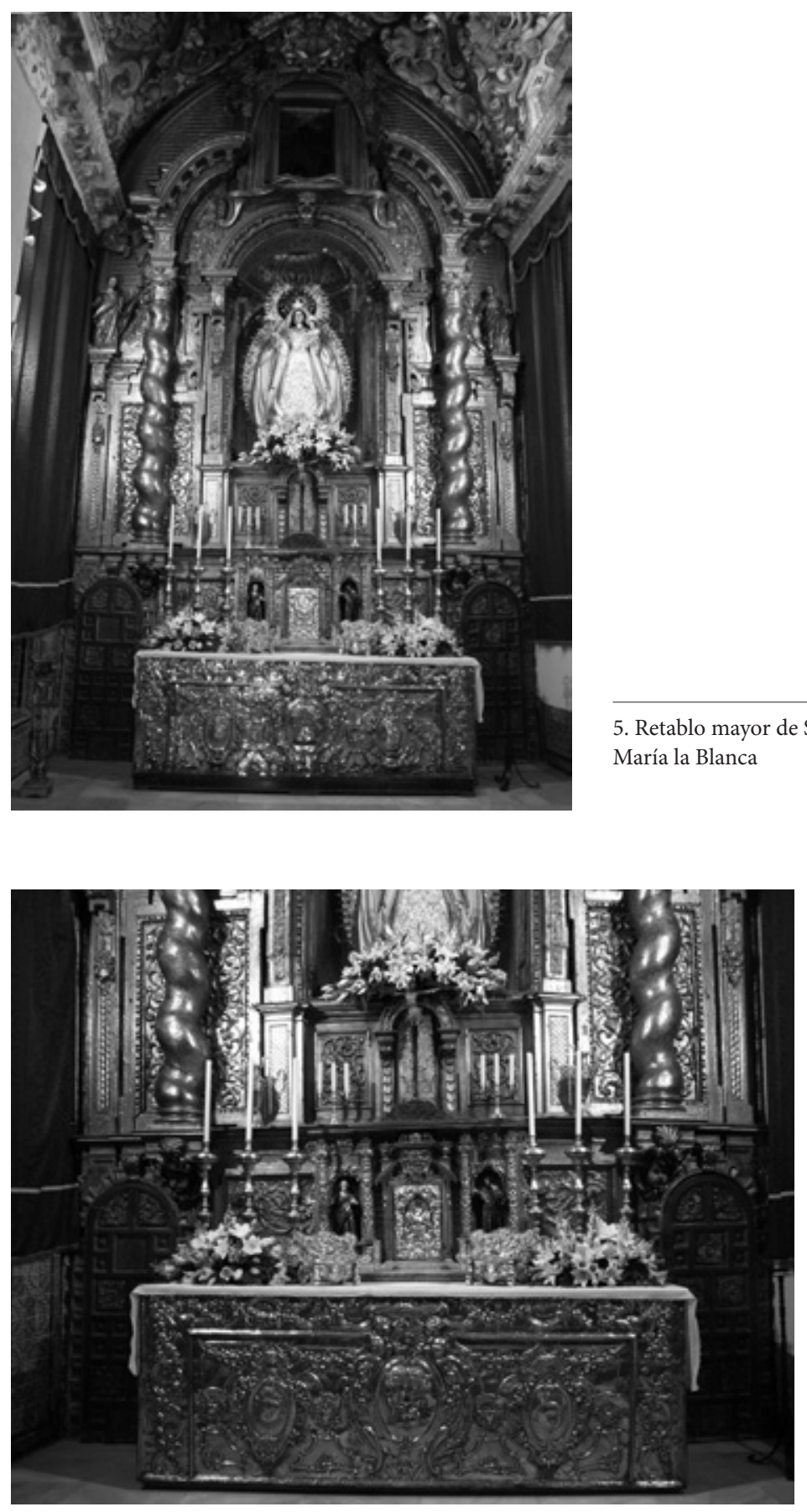


2 artículos $\quad$ El arquitecto de retablos...

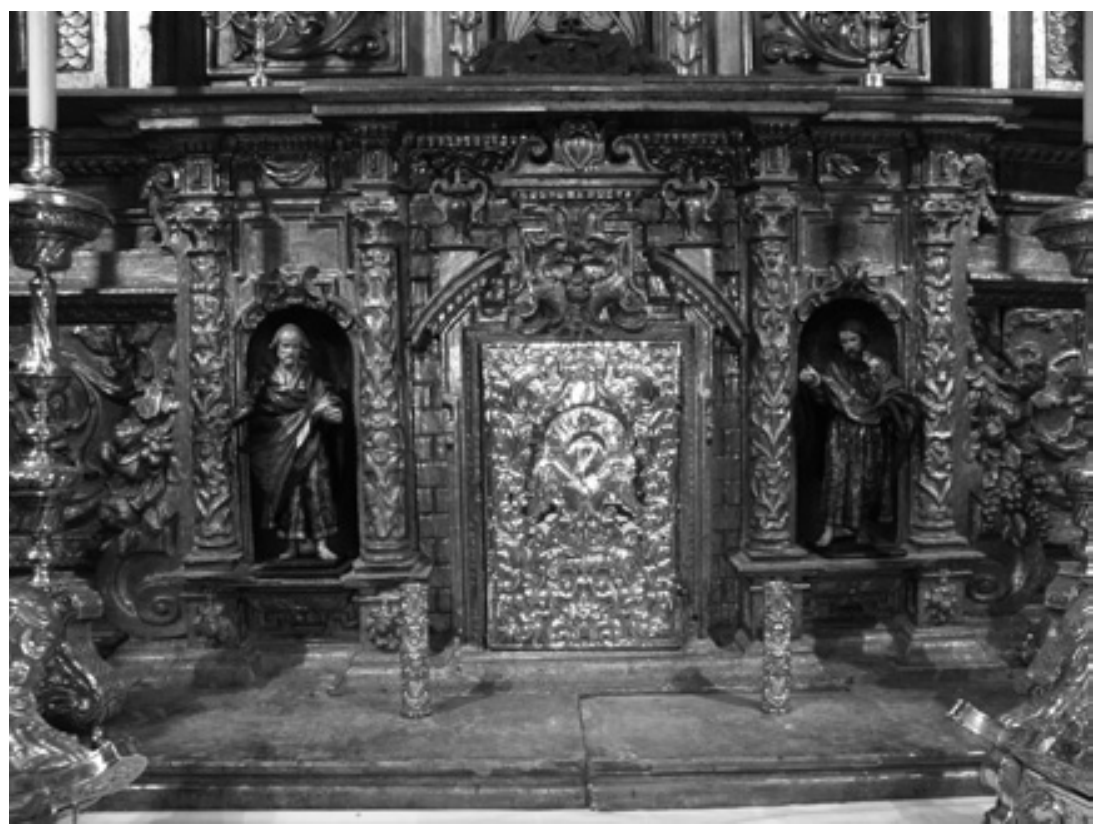

7. San Pedro y San Pablo

pacio se cubre con cúpula gallonada de media naranja, sobre pechinas, decorada con un plafón calado [8]. En el ático hay un gran arco semicircular peraltado y roto, con decoración de dentellones que alberga una hornacina, prevista inicialmente para el manifestador del Santísimo en los días festivos, como consta en el contrato. Desde mediados del siglo $\mathrm{XX}$ ha albergado una pequeña imagen de candelero de San Emigdio, obispo y mártir del siglo IV, natural de Ascoli Piceno (Italia), abogado de la peste y protector contra los terremotos. Tras la reciente restauración del templo ha sido reemplazado por una cruz de madera, de 1780, en la que figura la talla de la Giralda. El esquema del frontón roto que alberga un marco rectangular, deriva del frontispicio del tratado de Palladio. Completa la decoración escultórica en el remate la paloma del Espíritu Santo, y en las calles laterales, las tallas estofadas y policromadas de la Fe y de la Esperanza ${ }^{43}$ sobre repisas, que apean sobre ménsulas. A lo largo de todo el retablo hay guirnaldas de frutos, con racimos de uvas y granadas, temática que se repite en las yeserías de la nave central, que no

43 Así se indica en el «Inventario de los bienes de la iglesia de Santa María la Blanca, que se inicia en 1685». ACS, Sección 0, Libro 99 (07045), Fol. 27. La bibliografía tradicional indicaba que se trataba de las santas Justa y Rufina. Las tallas miden: $0.87 \mathrm{~m}$ y muestran brazos y manos parcialmente mutilados. 


\section{P: artículos}

Teodoro Falcón Márquez

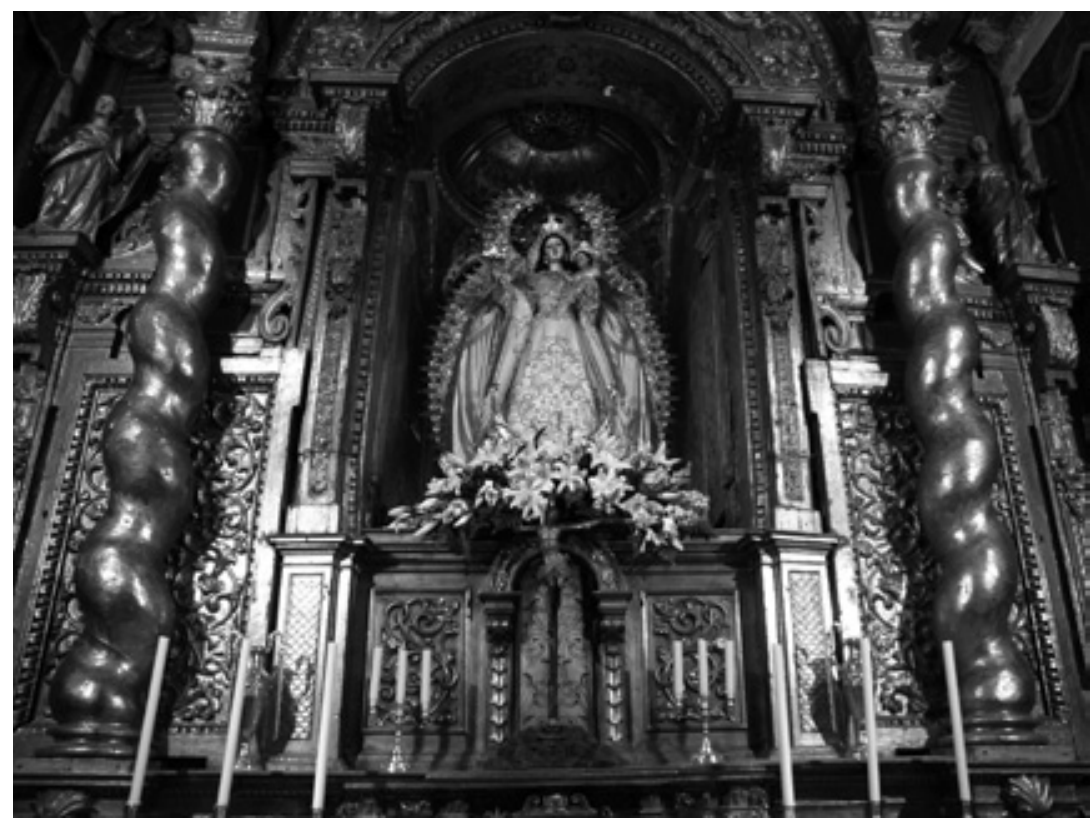

8. Camarín con la Virgen de las Nieves

se va a ejecutar hasta 1665. Otra nota decorativa del retablo son las pilastras con decoración de escamas. El ático, como el del retablo de la Concepción Grande, muestra también la decoración de almohadillado ${ }^{44}$.

La advocación de la iglesia de Santa María la Blanca, y de su imagen titular, la Virgen de las Nieves, está estrechamente vinculada a la construcción de la basílica de Santa María la Mayor de Roma. Según una piadosa tradición, la Virgen se había aparecido en sueños al patricio Juan y su esposa, en la noche del 4 de agosto del año 352, instándoles a la construcción de un templo en el monte Esquilino, en el lugar donde amaneciera nevado al día siguiente. El tema fue representado por Murillo en los dos grandes lunetos que se colocaron en 1665, bajo la bóveda semiesférica de la nave central de este templo sevillano, que se inauguró en ese año. Lo lienzos representan El sueño del patricio Juan y su esposa y La visita al pontífice Liberio. Tras ser confiscados por el mariscal Soult, después de diversas vicisitudes en la actualidad se hallan en el Museo Nacional del Prado. La imagen de la Virgen de las Nieves que preside este retablo no es la primitiva.

44 El frontal de plata mide: $0,97 \times 2,81$. Es uno de los más importantes del barroco sevillano. Fue realizado en 1787 por Antonio Agustín Méndez. En las marcas pone: A. Méndez, García, el NO8DO y la Giralda. 
La iconografía más antigua que conocemos data de 1665. Figura en un grabado, realizado por Matías de Arteaga, que se halla en la primera página de un libro de Torre Farfán ${ }^{45}$. La Virgen viste un ampuloso traje, a modo de guardainfante. A sus pies hay diez querubines y dos ángeles-niños que hacen de atlantes, más el perfil cónico del monte nevado. La imagen era entonces de talla, tal vez medieval, remodelada en el siglo XVI y de nuevo en 1665. Hay constancia de nuevos arreglos en 1673 y en $1791^{46}$. La actual imagen de candelero se viene atribuyendo a Juan de Astorga (1777-1849). Sin embargo se hizo de nuevo, por un escultor anónimo, depositándose en su retablo el 5 de agosto de $1864^{47}$.

45 TORRE FALFÁN, Fernando de la, Fiesta que celebró la iglesia parrochial de Santa María la Blanca, capilla de la Santa Iglesia Metropolitana y Patriarchal de Sevilla en obsequio del nuevo Brevr concedido por N. Smo. Padre Alexandro VII a favor del Purísimo Mysterio de la Concepción sin culpa original de María Santísima Nuestra Señora en el primer instante physico de su ser. Con la circunstancia de averse fabricado de nuevo su templo para esta fiesta, en Sevilla, por Ivan Gómez de Blas, su impresor mayor. Año de 1665.

46 ACS Sección IV. 05256 (1237). Gastos de la Fábrica de Santa María la Blanca. F. 120. APSN, Fondos de la iglesia de Santa María la Blanca. Libro de las hermandades que comienza en 1696. Cabildo de 28 de noviembre de 1791, Fol. 225v.

47 MORGADO, Alonso. Sevilla mariana. Sevilla, 1882, p. 93. 
